\title{
Using ELSA App in Speaking Classes: Students' Voices
}

\author{
Endang Darsih ${ }^{1}$, Marwito Wihadi ${ }^{2}$, Agie Hanggara ${ }^{3}$ \\ English Education Department, Universitas Kuningan \\ \{endang.darsih@uniku.ac.id\}
}

\begin{abstract}
T Covid-19 has caused a sudden shift from face to face teaching method to online learning that requires teachers and lectures as well to utilize technology. It also has made a significant surge in usage of online learning applications, video conferencing tools and language apps since COVID-19. One of language learning apps which is used by university students is ELSA Speak App. Hence, in the present study, four classes of students from English Education study program were surveyed to elicit their perceptions toward the use of ELSA App. By using a questionnaire adopted from Martins, Levis and Borges (2016), it is revealed that the majority of the students agreed that ELSA Speak App is a useful tool to improve their speaking ability particularly pronunciation aspect
\end{abstract}

Keywords: ELSA App; Speaking Classes; pronunciation

\section{Introduction}

All walks of society have been impacted by the Covid-19 pandemic and the social distancing that resulted, including education. Educational institutions have had to rapidly adjust to the situation in order to keep education going. This has contributed to an unprecedented movement towards online learning [1] [2] [3]. Many have rushed to provide their assistance and 'solutions', even for free, including commercial digital learning platform providers [1] as they can be seen as a way to address many of the challenges posed by the Covid-19 pandemic. In university level, the challenge of using online platforms has been valuable insights into the existing online tertiary scenario have also been provided Education continues in the form of COVID-19. [4] As the pandemic interfered with their academic functioning, students endured major education disturbances [5]. Face-to-face teaching/learning has been suspended since the closing of tertiary-level educational institutions. It disrupted the daily flow of academic programs from sessions [6]. The delay in re-opening schools can have a negative effect on their mental state and academic development [7]. The long-term home quarantine period caused disruption and degradation in the study patterns and work performance of students, ultimately leading to increased stress and unstable learning behaviors [8].

During the COVID-19 situation, a significant shift in many educational institutions to emergency online learning programs from traditional face-to-face learning programs was observed to reduce disruptions in tertiary education. But research has revealed that Students were uncomfortable and distressed by the strategy for online learning [9]. They encountered difficulties in transitioning to online lectures, adjusting new methods and workloads of online evaluation, communicating with teachers, and addressing many problems of online education, such as unavailability of electronic devices, no access to the internet, high internet costs, etc [10]. If technical advancement involving the Internet and computer applications takes place, we need to consider new advancements in online education. Educators need to provide a 
meaningful and creative experience for any online student with this knowledge. Different approaches to web design and development that understand mobile responsiveness must be considered by educators. The aim is to create a visual interface that is mobile-friendly and enables detailed viewing in all online environments. Bearing in mind that online learning can take place anywhere, anywhere - the rise of mobile devices can generate new directions for online education. Using collaborative resources, this method will allow teachers, students, and remote experts to interact visually with each other. Collaborative resources can allow more open knowledge that can lead to new models of online learning. Models of borderless online networks can be created by collaborative tools and their applications. Thus, the approach of borderless networks can create dynamic online learning opportunities [11].

Via a series of activities ranging from testing the attendance of the students to giving score on the works of the students synchronously or asynchronously depending on each school policy, the EFL teachers carried out online learning. Various applications and platforms are used, ranging from a method of learning management to external tools. [12] [13]. The use of MALL (Mobile Assisted Language Learning) nowadays is a prerequisite for schools and universities to continue the teaching process. This cannot be distinguished from the government's advice to carry out a learning process from home that is safer for education. MALL use is defined by cellular learning. Students may use the characteristics that are on the cellular devices when conducting the learning activities, such as video, audio, mp3 and so on. The use of MALL is considered to make it easier for students to access learning materials from anywhere, including from their homes. However, the unstable connection triggers online learning disrupted via MALL. [14].

Despite some limitations, the use of wireless mobile technologies such as mobile phones, tablets and laptops, is now being used for online learning [11]. It is also proven tobe effective in teaching college students particularly in speaking courses [15] Almost all university students now have their hands on cell phones and the internet. They all have a smart phone which they can use to access the internet. A study found that phones (42 percent), followed by tablets (7 percent) are the most used devices by college students. [16]. Portability and speed are the advantages of these units. Besides, mobile applications are found to be helpful for them in learning English such as ELSA Speak App in speaking class [17]. "ELSA Speak: English Accent Coach" can be downloaded on the smart phone via play/app store. It is designed to help students speak English in a simple, fluent and confident manner. The features given in this app are intended to allow learners to correctly say words such as vowel, consonant, word stress. During pandemic, the student cannot reach the lecturer directly in the speaking subject, therefore the lecturer gives the students the task of practicing their speech using the ELSA Speak app to sustain their English learning well at home.

Since teaching speaking is not an easy task, and speaking inhibitions are also caused by external factors such as lecturers' role [18] therefore lecturers need to provide students more advanced treatment, practice-oriented sessions and successful means of enforcing it [19] such as offering them mobile applications which are able to help students learning and practicing speaking. By integrating appropriate technology, mobile learning can also promote their learning autonomy [20]. The present study aimed at investigating student's voices regarding the use of mobile application named ELSA App in speaking classes. 


\section{Method}

The present study employed a quantitative survey method to obtain data about students' voices or perspectives toward the use of Elsa App in speaking classes. Four classes of students were selected purposively and participated in this study. Purposive sampling helps the researcher select respondent with particular characteristics to best understand the research problem and answer the research questions [21]. 94 students from English education study program filled the questionnaires adopted from Martins, Levis and Borges [22] The total questions on a questionnaire are 25 items while there are 5 question for each aspect aims to find out the EFL learners' perspective on using ELSA Speak app in their pronunciation ability.

The questionnaire is used to get validity relate to EFL learners' perspective on using ELSA Speak app on their speaking ability particularly pronunciation aspect. In complementing the questionnaire, the participants are expected to choose the most appropriate option of 4-level Likert Scale labeled by strongly disagree, disagree, agree, and strongly agree. The questionnaire consists of 5 aspects on the ELSA Speak App such as content, pedagogical, assessment/flexibility, multimedia and automatic speech recognition. The data then were analyzed quantitatively using the score interpretation criteria.

\section{Result and Discussion}

The results of the questionnaires are seen in Graph 1:

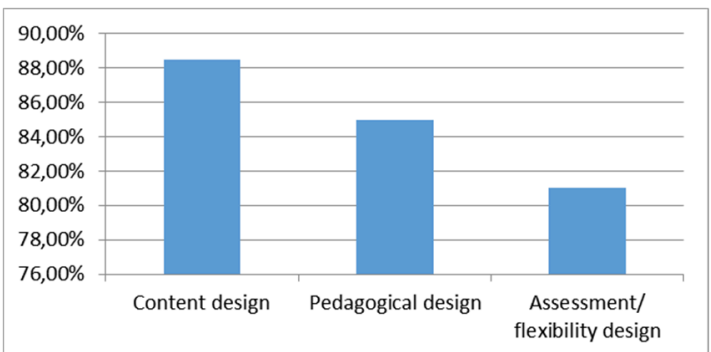

The graphs is the result of questionnaires about students' perspectives toward ELSA Speak App. Based on the results, it is seen that regarding the students' perspective towards the content design of the ELSA Speak app shows the total score of the students answer was 86.5 $\%$. Thus, it means that it is included in the strongly agree category. It indicates more than half of student were like the content in ELSA Speak app in learning speaking. Based on the data, it can be stated that the students consider that the content design of the ELSA Speak app is very good. The content in ELSA Speak such as audio voice, phonetic transcript, vocabulary, conversation audio, quiz of ELSA Speak application was able to help the learners and motivate them to practice their pronunciation. the program highly addresses the content according to the proposed objective and proficiency level.

In addition, the program also addresses the vowel sounds, the diphthongs, the consonant sounds, syllabic constituent, word/ sentence stress, prominence, connected speech phenomena, and intonation in a good way. It can be concluded that EFL learners' perspective towards the content in ELSA Speak application is good. The result of the questionnaire regarding the students' perspective towards the pedagogical design of the ELSA Speak app shows the total 
score of the students' answer is $85 \%$. Thus, it means that it is included in the strongly agree category. It indicates more than half of student were like the pedagogical design in ELSA Speak app. This application uses phonetic symbols and transcriptions which help them to learn English language. The students consider that the pedagogical design of the ELSA Speak software is very good. Hence, it can be assumed that the program contrasts different vowel sounds and different consonant sounds as well.

Besides, it also presents and distinguishes grammatical and semantic intonation patterns as well. The program uses phonetic symbols and transcriptions. It also presents the contents organized sequentially. Regarding the activities, it works on clearly production of sounds and instruction. It can be concluded that the pedagogical design in ELSA is very helpful for the learners because there are a lot of features to practice speaking especially pronunciation with the grammatical and phonetic transcription which help the users to get easier in pronouncing the words in English properly.

The result of the questionnaires regarding the students' perspective towards the assessment/ flexibility design of the ELSA Speak software shows the total score of the students' answer is $81 \%$. Thus, it means that it is included in the agree category. It indicates $81 \%$ more than half of student were like the assessment in ELSA Speak app. ELSA Speak app assessment is appropriate for them to learn English pronunciation and making a correction of their pronunciation. Based on the data, it can be stated that the students consider that the assessment/ flexibility design of the ELSA Speak software is very good. The students strongly agree that regarding the feedback of the activities, it gives good explanation. In addition, regarding the activities, the students can choose their difficulty level and know the result as well. It can be concluding the assessment in ELSA Speak application is giving facility to the user for evaluate their pronunciation.

\section{Conclusion}

Students are interested in learning speaking by using the ELSA Speak app. They decided that the ELSA Speak app is an online program that can have a beneficial impact on speech learning. The ELSA Speak App inspires learners to learn pronunciation and vocabulary. In addition, the ELSA Speak app offers audio, vocabulary, and phonetic transcription facilities to assist them in learning pronunciation and vocabulary. In addition to all of the benefits obtained from the ELSA Speak app, however some students had trouble because there was some level that was still locked and should be charged. The ELSA Speak app's audio response is still not strong enough to filter out the noise from the outside, so users have to repeat their voice.

\section{References}

[1] J. S. \&. M. C. Teräs M, "Post-Covid-19 Education and Education Technology, 'Solutionism': a Seller's Market," Postdigital Science and Education, vol. 2, p. 863-878, 2020.

[2] A. Abidah, H. N. Hidaayatullaah, R. M. Simamora, D. Fehabutar dan L. Mutakinati, "The Impact of Covid-19 to Indonesian Education and Its Relation to the Philosophy of "Merdeka Belajar"," Studies in Philosophy of Science and Education (SiPoSE), vol. 1, no. 1, pp. 38-49, 20201.

[3] Pietro, F. Biagi dan C. P, "The likely impact of COVID-19 on education: Reflections based on the existing literature and recent international dataset," Publications Office of the European Union, Luxembourg, 2020. 
[4] S. Dutta dan M. K. Smita, "The Impact of COVID-19 Pandemic on Tertiary Education in Bangladesh: Students' Perspective,” Open Journal of Social Sciences, vol. 8, pp. 53-68, 2020.

[5] N. E. Charles, "Increased mood disorder symptoms, perceived stress, and alcohol use among college students during the COVID-19 pandemic," online, 2020.

[6] O. N. Jacob, Abigeal dan A. \& Lydia, "Impact of COVID-19 on the Higher Institutions Development in Nigeria," Electronic Research Journal of Social Sciences and, vol. 2, pp. 126-135, 2020.

[7] O. Chandasiri, "The COVID-19: Impact on Education," Journal of Asian and African Social Science and Humanities, vol. 6, pp. 37-42, 2020.

[8] S. A. Meo, A. Abukhalaf, Alomar, K. Sattar dan D. \& Klonoff, "COVID-19 Pandemic: Impact of Quarantine on Medical Students' Mental Wellbeing," Pakistan Journal of Medical Sciences, vol. 36, pp. S43-S48., 2020.

[9] A. B. A. A. \&. A. L. Al-Tammemi, "Is It Just about Physical Health? An Internet-Based CrossSectional Study Exploring the Psychological Impacts of COVID-19 Pandemic on University Students in Jordan Using Kessler Psychological Distress Scale.," doi: https://doi.org/10.1101/2020.05.14.20102343, 2020.

[10] C. K. C. K. \&. H. D. Owusu-Fordjour, " The Impact of Covid-19 on Learning-The Perspective of the Ghanaian Student," European Journal of Education studies, vol. 7, pp. 88-101, 2020.

[11] C. W. Cook, "Technology And Online Education:Models for Change," Contemporary Issues In Education Research, vol. 7, pp. 171-188, 2014.

[12] A. N. Arief Eko Priyo Atmojo, "EFL Classes Must Go Online! Teaching Activities and Challenges during COVID-19 Pandemic in Indonesia," REGISTER JOURNAL, vol. 13, no. 1, pp. .49-76 , 2020 .

[13] M. Okmawati, "THE USE OF GOOGLE CLASSROOM DURING PANDEMIC," Journal of English Language Teaching, vol. 9, no. 2, pp. 438-443, 2020.

[14] A. J. Saragih E, "Implementing Mobile-Assisted Language Learning (MALL) in Writing Classroom: Pre-service Teacher's Opinions," dalam Prosiding Seminar Penelitian Dosen, Bogor, 2020.

[15] S. S. Darsih E, "Technology Integration in Public Speaking Classroom:is it effective/," dalam Proceedings of the 1st International Conference on Science and Technology for an Internet of Things, Yogyakarta, 2018.

[16] M. T. Al-Hariri, "Impact of students' use of technology on their learning achievements in physiology courses at the University of Dammam," Journal of Taibah University Medical Sciences, vol. 12, no. 1, pp. 82-85, 2017.

[17] A. N. Darsi E, "Mobile Assisted Language Learning; EFL Learners' Perceptions towards the use of Mobile Applications in Learning English,” ENGLISH REVIEW, vol. 8, no. 2, pp. 19-30, 2020.

[18] T. R. N. D. E. Afifah, "Analysis of students inhibitions in speaking skill," International Journal of Language and Instruction, 2020.

[19] M. K. Ahmed, "Pedagogy in Speaking: Challenges Addressed by Teacher-Student in the ESL ContextInternational Journal of Applied Linguistics \& English Literature," International Journal of Applied Linguistics \& English Literature, vol. 7, no. 3, pp. 90-97, 2018.

[20] E. Darsih, "Learner Centered Teaching; What makes it effective," Indonesian EFL Journal, vol. 4, no. 1, pp. 33-42, 2018.

[21] J. W. Creswell, The Research design: qualitative, quantitative and mixed methods approaches, California: Sage Publication., 2014.

[22] L. B. Martins, "The design of an instrument to evaluate software for ESL/EFL pronounciation teaching," Ilha do Desteiro, vol. 69, p. 155, 2016. 